\title{
Oxidative stress in female dogs with mammary neoplasms ${ }^{1}$
}

\author{
Claudia Russo ${ }^{2}$, Sandra Maria Simonelli³ , Marcela B. Luz ${ }^{4 *}$ (D) Alefe C. Carrera ${ }^{4}$, \\ Isabela F. Moreno ${ }^{4}$ and Ana Paula F.R.L. Bracarense ${ }^{5}$
}

\begin{abstract}
Russo C., Simonelli S.M., Luz M.B., Carrera A.C., Moreno I.F. \& Bracarense A.P.F.R.L. 2021. Oxidative stress in female dogs with mammary neoplasms. Pesquisa Veterinária Brasileira 41:e06742. Graduate Program in Animal Science, Departamento de Medicina Veterinária Preventiva, Universidade Estadual de Londrina, Rodovia Celso Garcia Cid 380, Londrina, PR 86057-970, Brazil. E-mail: mbaggioluz@gmail.com

The result of the reaction of free radicals with biomolecules is the formation of substances with the potential of inducing oxidative damage, a condition known as oxidative stress. There are voluminous literature data reporting the association, both as a cause and as a consequence, between different diseases and oxidative stress. In this study, 144 female dogs with mammary neoplasia were analyzed. The animals were submitted to clinical evaluation for disease staging, hematological evaluation, serum biochemistry (renal and hepatic function tests), and dosage of the oxidative damage biomarker, malondialdehyde (MDA), at the time of its approach and 30 days after treatment. A control group of 100 healthy animals was also submitted to determination of serum MDA levels. The mean age of the animals affected by mammary neoplasms was $9.88 \pm 2.95$ ( 4 to 14 ) years, while in healthy animals it was $2.31 \pm 1.90$ years ( 1 to 6$)$. Of the 144 animals, $113(78.9 \%)$ had malignant neoplasms, and $15,21,46,17$ and 14 animals were in clinical stage I, II, III, IV and V respectively and the carcinoma in a mixed tumor was the most frequent histological pattern in this group (26\%). Thirty-one animals were diagnosed with benign neoplasms and mammary adenoma was the most frequent histological pattern in 15 animals (51.61\%). Hematological changes in the preoperative period were observed in 44 (38.9\%) and 12 (38.7\%) animals with malignant and benign neoplasias, respectively, and there was a positive correlation between anemia and higher levels of MDA $(P=0.0008)$ for animals with malignant tumors. Regarding serum biochemical parameters, the most frequent alterations in animals with malignant neoplasms were elevated ALT levels in 12 animals (10.6\%), creatinine in 10 animals (8.84\%) and urea in eight animals (7.07\%). Females with benign neoplasms presented less occurrence of changes in these parameters. In the group of healthy animals (control), the mean serum MDA values were $12.08 \pm 4.18$, whereas in the pre-treatment group, mean MDA was $24.80 \pm 5.74$ for bitches with benign neoplasms and $32.27 \pm 10.24$ for bitches with malignant tumors. A significant increase $(P<0.001)$ in MDA levels was observed in animals with malignant mammary neoplasms when compared to healthy animals and with benign tumors. In addition, a significant reduction $(P<0.001)$ was observed 30 days after treatment in MDA levels (27.37 \pm 7.86$)$ in animals with malignant tumors. In conclusion, our results indicate an association between MDA seric levels and mammary neoplasms in dogs. The results suggest that this factor can be used as a biomarker of oxidative stress with a potential impact in the prognostic of mammary tumors, since significantly higher levels of MDA were detected especially in dogs carrying malignant tumors and presenting anemia.
\end{abstract}

INDEX TERMS: Oxidative stress, female dogs, mammary neoplasms, canine, free radicals, malondialdehyde, mammary tumors.

\footnotetext{
${ }^{1}$ Received on July 2, 2020.

Accepted for publication on September 10, 2020.

${ }^{2}$ Graduate Program in Animal Science, Universidade de Londrina (UEL), Rodovia Celso Garcia Cid 380, Londrina, PR 86057-970, Brazil.

${ }^{3}$ Centro de Ciências Agrárias, Universidade de Londrina (UEL), Rodovia Celso Garcia Cid 380, Londrina, PR 86057-970, Brazil.
}

\footnotetext{
${ }^{4}$ Curso de Medicina Veterinária, Universidade Cesumar, Avenida Guedner 1610, Maringá, PR 87050-900, Brazil. *Corresponding author: mbaggioluz@gmail.com

${ }^{5}$ Departamento de Medicina Veterinária Preventiva, Universidade de Londrina (UEL), Rodovia Celso Garcia Cid 380, Londrina, PR 86057-970, Brazil.
} 
RESUMO.- [Estresse oxidativo em cadelas com neoplasia mamária.] O resultado da reação de radicais livres com biomoléculas é a formação de substâncias que podem ser utilizadas como marcadores de dano oxidativo, condição mais conhecida como estresse oxidativo. Evidências científicas comprovam a relação, quer como causa, quer como consequência, entre muitas doenças e o estresse oxidativo. Neste estudo, 144 cadelas portadoras de neoplasia de mama, foram submetidas à avaliação clínica para estadiamento da doença, avaliação hematológica, testes de função renal e hepática e dosagem do biomarcador de dano oxidativo, malondialdeído (MDA), no momento de sua abordagem e 30 dias após realização de tratamento. Um grupo controle de 100 cadelas saudáveis foi submetido também à determinação dos níveis séricos de MDA. A idade média dos animais acometidos por neoplasias mamárias foi de 9,88 2,95 (4 a 14) anos, enquanto que nos animais saudáveis foi de 2,31 $\pm 1,90$ anos ( 1 a 6). Dos 144 animais, $113(78,9 \%)$ apresentavam neoplasias malignas, sendo que $15,21,46,17$ e 14 animais encontravam-se em estadiamento clínico I, II, III, IV e V respectivamente, e o carcinoma em tumor misto foi o padrão histológico mais frequente neste grupo (26\%). Trinta e um animais tiveram diagnóstico de neoplasias benignas, sendo que 7 estavam no estádio I, 16 no estádio II e 8 no estádio III e o adenoma mamário foi o padrão histológico mais frequente em 15 animais (51,61\%). Alterações hematológicas no período pré-operatório foram observadas em 44 (38,9\%) e 12 (38,7\%) animais portadores de neoplasias malignas e benignas, respectivamente, sendo que houve correlação positiva entre anemia e níveis mais elevados de $\operatorname{MDA}(P=0,0008)$, para os animais com tumores malignos. Em relação aos parâmetros bioquímicos séricos, as alterações mais frequentes nos animais com neoplasias malignas foram a elevação dos níveis de ALT em 12 animais $(10,6 \%)$, de creatinina em 10 animais $(8,84 \%)$ e de ureia em oito animais $(7,07 \%)$ Cadelas portadoras de neoplasias benignas apresentaram menor ocorrência de alterações nesses parâmetros. No grupo controle, a média dos valores séricos de MDA foi $12,08 \pm 4,18$, enquanto que no grupo pré-tratamento, a média de MDA foi de 24,80 $\pm 5,74$ para as cadelas com neoplasia benigna e 32,27 $\pm 10,24$ para as neoplasias malignas. Verificouse aumento significativo do valor sérico de MDA em cadelas portadoras de neoplasias malignas em comparação com os animais hígidos ou com neoplasias benignas $(P<0,001)$. Ainda, 30 dias após o tratamento observou-se uma diminuição significativa $(P<0,001)$ no valor médio de $\operatorname{MDA}(27,37 \pm 7,86)$ nos animais com neoplasias malignas. Em conclusão, os resultados deste estudo evidenciam uma associação entre níveis séricos aumentados de MDA e presença de neoplasias mamárias em cadelas. Os resultados sugerem que este fator pode ser utilizado como biomarcador de estresse oxidativo em cães, com provável impacto no prognóstico dos tumores mamários, uma vez que níveis significativamente mais altos de MDA foram detectados especialmente nas cadelas portadoras de tumores malignos e apresentando anemia.

TERMOS DE INDEXAÇÃO: Estresse oxidativo, cadelas, neoplasia mamária, caninos, malondialdeído, radicais livres, tumores de mama.

\section{INTRODUCTION}

Oxidative stress is a topic that has been drawing researchers' attention for years due to its correlations with processes such as aging and the appearance of some diseases. The formation of compounds called reactive oxygen specimens (ROS), occurs physiologically as part of cellular metabolism, and has important functions, such as the destruction of aggressive agents by phagocytosis (Schafer \& Buettner 2001).

In situations where there is an increase in the production of ROS, the body has an efficient antioxidant defense system capable of restoring balance (Finkel \& Holbrook 2000). When there is a loss of balance with a predominance of oxidizing agents, oxidative stress is established, which will lead to damage to the cell. The cell membrane, as well as the membranes of intracytoplasmic organelles of the nucleus, mitochondria and endoplasmic reticulum are the main sites of action of ROS (Barreiros et al. 2006). Cellular damage, results from the attack of ROS on the macromolecules that make up the membranes, such as carbohydrates, proteins and lipids. The lipid peroxidation of cell membranes resulting from the action of ROS culminates in chemical and physical changes, leading to changes in the fluidity and permeability of the membrane, with the risk of rupture and consequent cell death (Vasconcelos et al. 2007).

Oxidation products can react with each other and result in new products, which can be used as biomarkers of oxidative damage. Malondialdehyde (MDA) is currently considered a general biomarker of oxidative damage present in plasma (Kadiiska et al. 2005). A product of lipid peroxidation of cell membranes, its quantification in biological systems is an important parameter for the evaluation of cellular oxidative stress (Pilz et al. 2000, Sim et al. 2003). Andrade Júnior et al. (2005) and Del Rio et al. (2005) refer that MDA is highly cytotoxic and genotoxic, and should be considered more than a biomarker of oxidative damage, due to its interaction with DNA and other proteins. Elevated levels of MDA are routinely used as a means of detecting oxidative stress in various diseases in humans, such as systemic lupus erythematosus, diabetes, lung diseases, Alzheimer's disease, cancer, among others, which generates subsidies for research in animals (Ferreira \& Matsubara 1997, Andrade Júnior et al. 2005, Pérez et al. 2012). The most used technique for non-specific measurement of MDA is known as quantification of substances reactive to thiobarbituric acid or TBARS. This technique quantifies products called substances reactive to barbituric acid, among which MDA is the main component, but it is a technique of low sensitivity and specificity for the detection of aldehydes in biological fluids, which has justified the search for techniques of greater fidelity, such as MDA detection (Abdalla \& Sena 2008).

In veterinary medicine, previous studies have evaluated the occurrence of oxidative stress in dogs with lymphoma (Winter et al. 2009, Macedo 2010), heart failure (Freeman et al. 2005), mammary cancer (Szczubial et al. 2004) and kidney disease (Galvão 2009). Changes in oxidative status in animals with neoplasms (including mammary) were evidenced by measuring damage biomarkers, such as substances reactive to barbituric acid (TBARS) and nitric oxide, concentrations of metals such as iron, copper and zinc and antioxidants as ascorbic acid (Askar et al. 2009). The determination of prognostic factors in neoplasms, including mammary cancer, has been an object of growing interest in veterinary oncology, mainly with the use of immunohistochemistry and molecular diagnostic methods, that can detect the presence of markers frequently researched in 
mammary neoplasms, such as Ki- 67, E-cadherin, HER-2, COX-2, VEGF, p-53, among others (De Las Mulas et al. 2003, Thuróczy et al. 2007, Lavalle et al. 2009). However, data regarding the use of oxidative damage biomarkers, as well as their possible use as a prognostic marker, are scarce in the veterinary literature. The objective of this study was to evaluate the occurrence of oxidative stress in female dogs with mammary cancer before and after surgical treatment by measuring serum malondialdehyde, as well as to determine its possible association with the prognosis of the disease. In addition, the average MDA value in healthy female dogs was established for comparison purposes.

\section{MATERIALS AND METHODS}

Animals. This study included 144 female dogs with mammary cancer treated at two Veterinary School Hospitals located in the cities of Maringá, Paraná and Ourinhos, São Paulo. The study was approved by the Institutional Committees for the Use of Experimental Animals. After the consent of their guardians, the animals included in the study (pre-treatment group) underwent physical evaluation for clinical stage of the disease according to Cassali et al. (2014).

We also used 100 healthy, young female dogs, with ages varying from one to six years, to determine the serum values of malondialdehyde (control group), considering that there are no reference values for this biomarker in the canine species. The animals included in this group were sent to the Veterinary Hospital for elective ovariohysterectomy surgery. The inclusion criteria in the control group were general health status and hematological parameters assessed by means of complete blood count and biochemicals, including renal function (urea and creatinine) and liver enzyme activity (ALT and FA) within the reference values for the species.

Hematological and biochemical tests. The animals were subjected to blood collection for hematological and serum biochemical assessment, including renal profile with urea and creatinine levels, liver, with alanineaminotransferase (ALT) and alkaline phosphatase (FA) levels performed in the Clinical Pathology laboratories of the respective SchoolHospitals. Serum samples from each animal were used to measure the concentrations of malondialdehyde (MDA), performed in the nutrition and metabolism laboratory at "Universidade de São Paulo" (USP) in Ribeirão Preto/SP, Brazil. The examinations were performed at the time of the initial clinical approach and 30 days after the therapeutic procedure, taking into account the period required for postoperative recovery. To determine hematological parameters, the routine techniques described by Jain (1993) were used. The blood samples were placed in a flask containing the anticoagulant ethylene-diaminetetraacetic acid ( $3 \mathrm{ml}$ of blood). The total erythrocyte and leukocyte counts and the determination of the hemoglobin concentration were performed with an automatic cell counter (Celm CC 530/DA 500 ${ }^{\circledR}$, Brazil). The globular volume was determined by the microhematocrit method and the plasma protein concentrations by the refractometer method. The mean corpuscular volume (VCM) and the mean corpuscular hemoglobin concentration (CHCM) were calculated following the formulas described by Wintrobe (1974). For biochemical tests, blood samples (10ml) were collected from each animal by puncture of the jugular vein. The samples were placed in tubes without anticoagulant for the determination of the biochemical concentrations of urea and creatinine, and activity of the enzymes ALT and FA, following the protocol established by the manufacturer (specific commercial kits Gold Analisa ${ }^{\circledR}$ ). For the determination of urea and ALT, the kinetic-UV method was used and for the determination of creatinine and FA the kinetic-colorimetric method. The results were read and obtained using a Bioplus-2000 ${ }^{\circledR}$ photometric analyzer, Brazil.
Serum determination of malondialdehyde (MDA). To carry out the MDA dosage, samples of $5 \mathrm{ml}$ of blood were taken from the jugular vein, in tubes without anticoagulant, submitted to centrifugation to separate the serum. The serum was then placed in appropriate plastic tubes and frozen at $-20^{\circ} \mathrm{C}$ until processing. The serum measurement of MDA was performed according to the method proposed by GérardMonnier et al. (1998), with adaptations. For the measurement of MDA in serum, $100 \mu$ of the sample were used. To this was added $300 \mu \mathrm{l}$ of a $10 \mathrm{mM}$ solution of 1-methyl-phenylindol in acetonitrile and methanol $(2: 1, \mathrm{v} / \mathrm{v})$ and $75 \mu \mathrm{l}$ of $\mathrm{HCl}(37 \%)$. Soon after, the tubes were vortexed and incubated in a water bath at $45^{\circ} \mathrm{C}$ for 40 minutes. After the bath, the samples were cooled on ice and then the tubes were centrifuged at $4000 \mathrm{rpm}$ for 10 minutes. From the supernatant, absorbance was read on a spectrophotometer with a wavelength of $586 \mathrm{~nm}$. The MDA concentration was calculated by comparing it to a hydrolyzed 1,1,3,3-tetramethoxypropane (TMP) curve. The MDA determination exams were conducted at the Nutrition and Metabolism Laboratory of the Medical School in USP, Ribeirão Preto.

Therapeutic and diagnostic approach. After the clinical staging and the evaluation of the results of the laboratory exams, the female dogs were submitted to total unilateral, bilateral, or regional mastectomy, with removal of inguinal and/or axillary lymph nodes, according to the case, for therapeutic purposes and to perform histopathological analysis of neoplastic tissues and lymph nodes. The definitive diagnosis was determined by means of histopathological evaluation and the correction of clinical staging, when necessary, was performed through pathological staging after microscopic analysis of the lymph nodes. For female dogs which presented with new mammary formation, with an erythematous, painful and inflamed clinical aspect, that is, when there was a suspicion that it could be an inflammatory mammary carcinoma (primary or secondary), only incisional biopsy was indicated, for diagnostic purposes and for enable the choice of the most appropriate therapeutic approach and definition of prognosis.

Thirty days after the surgeries or biopsies were performed, the female dogs were submitted to blood collection again to repeat the same hematological and biochemical evaluations performed initially (post-treatment group). Six animals from the group of malignant tumors were not evaluated in this period, as they died or were euthanized due to complications. In the group of female dogs with benign tumors, two animals did not undergo surgical treatment due to changes found in biochemical tests that indicated impaired renal function. The female dogs that had the clinical diagnosis, later confirmed by histopathological examination, of primary or secondary inflammatory carcinoma were treated in a palliative way, with a multimodal analgesia protocol, including tramadol hydrochloride, dipyrone and non-steroidal anti-inflammatory drug (firocoxib, 5mg/ $\mathrm{kg} / \mathrm{SID}$ ), chemotherapy and supportive therapy.

Statistical analysis. The data for each phase were tested for normality by the Shapiro-Wilk test (Shapiro \& Wilk 1965) and for homogeneity of variances by the Bartlett test (Bartlett 1950). For comparisons within each group and between groups, analysis of variance was performed and in case of significance, the Tukey test (Cooley \& Tukey 1965) was performed. MDA values were tested for associations, in groups of animals in pre and post treatment, with benign and malignant tumors diagnosed by means of histopathological evaluation, with the variables age, clinical staging, histological pattern of the tumors, hematological and biochemical parameters. To compare the pre- and post-treatment moments, the paired t-test was performed. The software $\mathrm{R}$ was used for the analyzes considering $5 \%$ of significance. 


\section{RESULTS}

\section{Animals}

During the period of this study, 144 canine females with mammary cancer were examined. The average age of the affected animals was $9.88 \pm 2.95$ (4 to 14) years, while in healthy animals the average age was $2.31 \pm 1.90$ years ( 1 to 6 ). Regarding breed, the highest occurrences were of mixed breed animals (52/144), Poodle (17/144) and Pit Bull (8/144). In the control group, the predominance was also of mixed breed animals (89/100), Shih Tzu (4/100) and Poodle (3/100). Of the 144 animals, $113(78.9 \%)$ had malignant neoplasms and 31 animals $(21.52 \%)$ had a diagnosis of benign neoplasms.

Regarding the histological classification, the most frequent malignant mammary neoplasms were carcinomas in mixed tumor $(26.5 \%)$, carcinosarcomas (CASA - 15.92\%) and malignant adenoepitheliomas $(11.5 \%)$. The most frequent benign tumors were mammary adenomas $(51.61 \%)$ and mixed benign tumors $(32.2 \%)$.

Of the 144 female dods with mammary tumor, 136 were submitted to surgical treatment, six animals were submitted only to incisional biopsy and two animals did not undergo any type of surgical treatment. Of the 136 surgeries with a therapeutic objective performed during this study, 29 were bilateral total mastectomies, 99 animals were submitted to unilateral total mastectomy and 16 animals were treated using regional mastectomy. Inguinal or axillary lymphadenectomy was performed, uni or bilateral, according to the type of surgery performed. Of the 144 female dogs, 112 were not castrated at the time of diagnosis and were then subjected to ovariohysterectomy at the same time as mastectomies.

\section{Hematological and biochemical tests}

In animals with neoplasms, the results of hematological and biochemical tests were evaluated in the initial clinical approach and 30 days after the therapeutic procedure. The animals in the control group showed no changes in hematological or biochemical parameters. Hematological changes in the preoperative period were observed in 44 (38.9\%) and $12(38.7 \%)$ animals with malignant and benign neoplasms, respectively. In both groups of these animals, the most frequent changes were anemia and thrombocytopenia. Neutrophilic leukocytosis was observed in four bitches with malignant neoplasms in the pre-treatment period, with ulcerated tumors.

Regarding serum biochemical parameters, the most frequent changes in animals with malignant neoplasms were the elevation of ALT levels in 12 animals (10.6\%), creatinine in 10 animals (8.84\%) and urea in eight animals (7.07\%). Female dogs with benign neoplasms showed less occurrence of changes in these parameters. The most frequent alteration was the increase in serum creatinine level, observed in four animals (12.90\%). In both groups, a decrease in the number of animals with hematological and biochemical changes was observed after treatment.

\section{Serum determination of malondialdehyde (MDA)}

The mean values of MDA (nmol/dl) obtained in the control animals, with benign and malignant neoplasms were 12.08 $( \pm 4.18), 24.80( \pm 5.74)$ and $32.85( \pm 10.24)$, respectively. There was a significant increase in mean serum MDA levels in animals with neoplasms compared to control animals $(P<0.001)$. In addition, female dogs with malignant neoplasms showed significantly higher levels compared to animals with benign tumors $(P<0.001)$. Average serum MDA levels in animals with benign and malignant neoplasms before and after the therapeutic procedure are shown in Table 1.

When assessing the effect of the therapeutic procedure on MDA levels, a significant decrease $(P=0.0001)$ was found in serum MDA after the therapeutic procedure in animals with malignant neoplasms. However, in animals with benign tumors, MDA levels did not differ before and after treatment (Table 1).

The relationship between MDA levels in animals with neoplasms and the other parameters was evaluated. For female dogs with benign tumors, both before and after treatment, no statistically significant difference was observed between MDA levels and the age of the animals, clinical staging, presence of hematological or biochemical alterations and histological classification of the tumors.

In animals with malignant tumors, an association between serum MDA levels and hematological changes and histological classification was observed only in the pre-treatment period. However, regarding the histological classification, it was observed that female dogs with solid carcinomas had a significantly lower MDA level than the other histological types. Regarding the presence of hematological changes, it was found that animals with anemia had the highest levels of MDA ( $P=0.0008)$ (Table 2).

\section{DISCUSSION}

The increase in the occurrence of neoplasms in companion animals has been associated with an increase in longevity due to improved animal nutrition and health (Ribas et al. 2012). International data on the risk of developing malignant mammary

Table 1. Means and standard deviations of serum malondialdehyde ( $\mathrm{nmol} / \mathrm{mL}$ ) in animals in the control group, with benign and malignant neoplasms, before and after treatment

\begin{tabular}{lcc}
\hline \multicolumn{1}{c}{ Groups } & Before treatment & $P$ value \\
\hline Control & $12.08 \pm 4.18 \mathrm{c}$ & \\
Benign & $24.80 \pm 5.74 \mathrm{~b}$ & $<0.001$ \\
Malignant & $32.85 \pm 10.24 \mathrm{a}$ & \\
Benign & & \\
$\quad$ Before treatment & $24.80 \pm 5.75 \mathrm{a}$ & 0.7506 \\
$\quad$ After treatment & $24.58 \pm 5.18 \mathrm{a}$ & \\
Malignant & & \\
$\quad$ Before treatment & $32.85 \pm 10.24 \mathrm{a}$ & 0.00013 \\
$\quad$ After treatment & $27.37 \pm 7.86 \mathrm{~b}$ &
\end{tabular}

Means followed by different letters in the same column differ by the Tukey test $(P<0.05)$.

Table 2. Association between anemia and higher serum levels of malondialdehyde (MDA) in the group of malignant neoplasms, in pre-treatment

\begin{tabular}{ccc}
\hline Anemia & MDA (nmol) & $P$ value \\
\hline Yes $(\mathrm{n}=37)$ & $40.88 \pm 7.51$ & $0.000844^{*}$ \\
No $(\mathrm{n}=76)$ & $27.80 \pm 8.23$ &
\end{tabular}


tumors in the canine species indicate variations between two and 58\% (Itoh et al. 2005, Macewen \& Withrow 2007). In Brazil, the occurrence of malignant mammary neoplasms is higher than the international average, being above $80 \%$ (Zuccari et al. 2001, De Nardi et al. 2002, Martins et al. 2002, Oliveira et al. 2003). In the present study, the occurrence of malignant mammary neoplasms $(78.5 \%)$ was similar to national data. This elevated occurrence was associated with the action of sex hormones, mainly in non-castrated female dogs before the first or second heat (Lana et al. 2007). In this study, $77.8 \%$ of the animals were not castrated at the time of mammary cancer diagnosis, showing ovarian hormonal activity. Regarding age, the results of this study (mean age 9.9 years) are in line with data in the literature that report a higher incidence of mammary cancer in animals aged seven to 12 years old (De Nardi et al. 2016).

The histological patterns most frequently diagnosed in mammary neoplasms vary widely according to the authors. The great histogenetic variability of mammary neoplasms, led to the need for standardization of classifications, highlighting the classifications of Misdorp et al. (1999) and Goldschmidt et al. (2011) previously used. In Brazil, Cassali et al. (2014) proposed a new classification that was used in this study. The most frequent histological pattern observed was carcinoma in a mixed tumor (26.54\%). Carcinoma in a mixed tumor is characterized by the presentation of a component of malignant epithelial origin and a component of mesenchymal origin with benign characteristics, with the presence of microinvasion, that is, a histological characteristic related to the worst prognosis (Cassali et al. 2014). There was no statistically significant correlation between the highest levels of MDA and the histological pattern of neoplasms, however, a statistically significant correlation was observed between lower levels of MDA and tumors diagnosed as solid carcinomas, which amounted to $7.1 \%(n=8)$ of the tumors diagnosed in this study. Solid carcinomas are considered frequent tumors in the canine species, generally as an evolution of large tumors in dogs that have not been surgically treated in earlier stages of the disease (Cassali et al. 2014).

In female dogs with malignant neoplasm with a diagnosis of solid carcinoma, no significant difference was observed when compared to other histological patterns with respect to the number of affected mammarys, clinical staging and hematological or biochemical changes, but a significant difference was found in relation to the average age in this group (7.1 \pm 1.4 years) when comparing the mean age of all female dogs with malignant mammary cancer (9.88 \pm 2.95$)$, which may be related to the lower serum MDA values found in this group (19.32 \pm 8.81$)$, justifying the need to establish MDA reference values according to the age group.

The clinical staging of mammary cancer in the dog is a moment in which the extent of the disease and its severity must be detailed, and it can be cited as an extremely important stage in the diagnosis, as, as well as the histological patterns of mammary tumors, the clinical staging of the disease is directly related to the scope of the therapeutic approach and prognosis. In this study it was found that 39\% of the female dogs were in clinical stage III (Lana et al. 2007).

At this stage of the disease, the tumors are larger than $5 \mathrm{~cm}$ in their maximum diameter, but without evidence of migration to lymph nodes or distant metastasis. However, when only female dogs with malignant neoplasms were evaluated, it was found that $68 \%$ were in clinical staging between III and V. There are no studies in the literature consulted showing the most frequent clinical staging in female dogs with mammary cancer at the time of the diagnostic approach, however, later staging may be related to more aggressive histological patterns (Ribas et al. 2012). In patients of the human species, late diagnoses are related to a low level of education, with a low rate of mammary self-examination (Monteiro et al. 2003, Pires 2007). According to Toríbio et al. (2012), the late search for veterinary medical assistance by the tutors of female dogs with mammary cancer is directly related to the socioeconomic characteristics of the population, highlighting in their study the need for guidance programs that emphasize the importance of early diagnosis of mammary cancer in bitches in order to provide a better prognosis.

Many diseases, which affect humans and animals, are related to oxidative stress caused by reactive oxygen or nitric oxide species. The most serious damage is that caused to the cell's DNA or RNA. When the DNA chain breaks, it can reconnect to another position, changing the order of its bases. This event is one of the processes that trigger mutation, which may be related to oncogenesis. In the present study, the lipid lipoperoxidation marker of cell membrane components, the MDA, considered a biomarker of oxidative damage, showed a significant serum increase (2.0 and 2.7 times) in benign and malignant neoplasms, respectively in relation to control. Similar results have been reported in women with mammary cancer by assessing levels of antioxidant capacity and serum levels of MDA (Sener et al. 2007). In animals, studies on the association between neoplasms and oxidative stress are scarce. Significantly higher levels of MDA were observed in dogs with different types of neoplasms, including mammary cancer compared to healthy animals (Macotpet et al. 2013). In this work, the serum concentration of MDA was determined by the method known as TBARS, that is, by the serum determination of substances reactive to barbituric acid, where MDA is the main component. Other studies also indicate the relationship between oxidative damage and the development of mammary tumors in female dogs, correlating, mainly, serum and tissue values of MDA, using the TBARS technique, and also of antioxidant levels such as vitamin E and vitamin C (Szczubial et al. 2004, Francisco Neto et al. 2005, Kumaraguruparan et al. 2005, Askar et al. 2009, Galvão 2009). In addition, Askar et al. (2009) demonstrated the existence of increased concentrations of MDA and nitric oxide (NO) and decreased serum concentrations of vitamin C, considered the first line of antioxidant defense, in 10 female dogs with malignant mammary cancer. In addition to the oxidative stress detected, according to this author, the decrease in antioxidant defenses such as vitamin $\mathrm{C}$, could be related to carcinogenesis. In the present study, much higher values in bitches with malignant neoplasms, and also higher values in the group of benign tumors support the statement that the presence of mammary cancer is related to oxidative stress. Another aspect to be highlighted was the significant decrease (0.8 times) in the levels of MDA in animals with malignant tumors after treatment, which indicates a reduction in oxidative stress after removal of the tumors.

Anemia is considered to be one of the most frequent hematological changes in cancer patients, and may be related 
to bone marrow infiltration by neoplastic cells, more common in systemic diseases, such as lymphoma. It may also be related to the cytotoxic effects of drugs during treatment, secondary to blood loss, hemolysis, usually immune-mediated and also, by inflammatory cytokines related to chronic disease (Vail \& Thamm 2005, Kobune et al. 2008). In the present study, it was found that female dogs with malignant mammary neoplasms showed a significant correlation between the presence of anemia and higher serum levels of MDA. However, after treatment, this significant difference was no longer observed, suggesting that oxidative stress is related to the occurrence of anemia in animals with malignant mammary tumors. In dogs with multicentric lymphoma an increase in lipid membrane lipoperoxidation was observed, through increased concentrations of TBARS, without correlating, however, the oxidative stress condition with anemia (Lucas et al. 2008, Winter et al. 2009). In human patients with lymphoma, elevated TBARS concentrations have been associated with increased lipid peroxidation in the erythrocyte membrane resulting in increased osmotic fragility and erythrocyte death (Abou-Seif et al. 2000). In children with acute lymphoblastic leukemia, the condition of oxidative stress was also detected by checking for high concentrations of TBARS, considered as one of the causes of anemia in these patients (Ghosh 2005).

\section{CONCLUSIONS}

The results of this study indicate that oxidative stress is associated with mammary cancer in dogs in a similar way to that reported in women. Due to the detection of significantly higher concentrations of serum MDA in female dogs with malignant mammary cancer, when compared to groups of benign neoplasms and control, and also in female dogs with anemia, it can be said that the identification of the oxidative stress state in these animals, can also be used as a prognostic factor. It should also be noted that in this study, MDA levels were directly measured, in contrast to other studies in which oxidative stress was indirectly verified, using substances reactive to barbiturates (TBARS). Another important aspect is the need to expand studies to determine reference parameters in the canine species for MDA and other oxidative damage biomarkers.

The measurement of oxidative stress biomarkers or even antioxidant substances from serum or tissues, may enable a series of new information from research that shows the relationship between free radicals and diseases, either as a cause or as an effect pathological conditions. The importance of using antioxidants as an adjuvant treatment that aims to minimize oxidative damage, or prophylactically, can also be the object of study in dog medicine.

Studies that seek the standardization of laboratory techniques and the definition of parameters that can be used as a reference in different species of veterinary medical interest will be of great use.

Conflict of interest statement.-The authors declare having no competing interests.

\section{REFERENCES}

Abdalla D.S.P. \& Sena K.C.M. 2008. Biomarcadores de peroxidação lipídica na aterosclerose. Revta Nutr. 21(6):749-756.<http://dx.doi.org/10.1590/ s1415-52732008000600013>
Abou-Seif M.A.M., Rabia A. \& Nasr M. 2000. Antioxidant Status, erythrocyte membrane lipid peroxidation and osmotic fragility in malignant lymphoma patients. Clin. Chem. Lab. Med. 38(8):737-742. <https://dx.doi.org/10.1515/ CCLM.2000.104><PMid:11071066>

Andrade Júnior D.R., Souza R.B., Santos S.A. \& Andrade D.R. 2005. Os radicais livres de oxigênio e as doenças pulmonares. J. Bras. Pneumol. 31(1):60-68. <http://dx.doi.org/10.1590/S1806-37132005000100011>

Askar T.K., Salmanoglu B., Salmanoglu R., Erkal N. \& Beskaya A. 2009. Changes in oxidative status and trace element levels in dogs with mammary tumors. Acta Vet., Belgrado, 59(4):405-411.<https://dx.doi.org/10.2298/ AVB0904405A>

Barreiros A.L.B.S., David J.M. \& David J.P. 2006. Estresse oxidativo: relação entre geração de espécies reativas e defesas do organismo. Quím. Nova, São Paulo, 29(1):113-123.<https://dx.doi.org/10.1590/S0100-40422006000100021>

Bartlett M.S. 1950. Tests of significance in factor analysis. Brit. J. Math. Stat. Psychol. 3(2):77-85. <https://dx.doi.org/10.1111/j.2044-8317.1950. tb00285.x>

Cassali G.D., Lavalle G.E., Ferreira E., Estrela-Lima A., De Nardi A.B., Ghever C., Sobral R., Amorim R.L., Oliveira L.O., Sueiro F.A., Beserra H.E.O., Bertagnolli A.C., Gamba C.O., Damasceno K.A., Campos C.B., Araujo M.R., Campos L.C., Monteiro L.N., Nunes F.C., Horta R.S., Reis D.C., Luvizotto M.C.R., Magalhães G.M., Raposo J.B., Ferreira A.M.R., Tanaka N.M., Grandi F., Ubukata R., Batschinski K., Terra E.M., Salvador R.C.L., Jark P.C., Delecrodi J.E.R., Nascimento N.A., Silva D.N., Silva L.P., Ferreira K.C.R.S., Freshe M.S., Di Santis G.W., Silva E.O., Guim T.N., Kerr B., Cintra P.P., Silva F.B.F., Leite J.S., Mello M.F.V., Ferreira M.L.G., Fukumasu H., Salgado B.S. \& Torres R. 2014. Consensus for the diagnosis, prognosis and treatment of canine mammary tumors. Braz. J. Vet. Pathol. 7(2):38-69.

Cooley J.W. \& Tukey J.W. 1965. An algorithm for the machine calculation of complex Fourier series. Math. Comput. 19(90):297-301. <https://dx.doi. org/10.1090/S0025-5718-1965-0178586-1>

De Las Mulas J.M., Ordas J., Millan Y., Fernández-Soria V. \& Cajal S.R. 2003. Oncogene HER-2 in canine mammary gland carcinomas: na immunohistochemical and chromogenic in situ hybridization study. Mammary Cancer Res. Treat. 80(3):363-367. <https://dx.doi.org/10.1023/a:1024929730165> <PMid:14503809>

De Nardi A., Ferreira T.M.M.R. \& Assunção K.A. 2016. Neoplasias mamárias, p.499-516. In: Ibid. (Eds), Oncologia em Cães e Gatos. Roca, São Paulo.

De Nardi A.B., Rodaski S., Sousa R.S., Costa T.A., Macedo T.R., Rodigheri S.A., Rios A. \& Piekarz C.H. 2002. Prevalência de neoplasias e modalidades de tratamentos em cães, atendidos no hospital veterinário da Universidade Federal do Paraná. Arch. Vet. Sci. 7(2):15-26. <https://dx.doi.org/10.5380/ avs.v7i2.3977>

Del Rio D., Stewart A.J. \& Pellegrini N. 2005. A review of recent studies on malondialdehyde as toxic molecule and biological marker of oxidative stress. Nutr. Metab. Cardiovasc. Dis. 15(4):316-328. <https://dx.doi. org/10.1016/j.numecd.2005.05.003>

Ferreira A.L.A. \& Matsubara L.S. 1997. Radicais livres: conceitos, doenças relacionadas, sistema de defesa e estresse oxidativo. Revta Assoc. Med. Bras. 43(1):61-68. <https://doi.org/10.1590/S0104-42301997000100014>

Finkel T. \& Holbrook N.J. 2000. Oxidants, oxidative stress and biology of ageing. Nature, Londres, 408(6809):239-247. <https://dx.doi. org/10.1038/35041687><PMid:11089981>

Francisco Neto A., Silva J.C.C.B., Fagundes D.J., Percários N.F., Juliano Y. \& Moreira Neto A.A. 2005. Estudo das alterações oxidativas, da capacidade antioxidante total e do óxido nítrico, em ratos submetidos à isquemia e reperfusão de membros posteriores. Acta Cir. Bras., São Paulo, 20(2):48-56. <https://dx.doi.org/10.1590/S0102-86502005000200006>

Freeman L.M., Rush J.E., Milbury P.E. \& Blumberg J.B. 2005. Antioxidant status and biomarkers of oxidative stress in dogs with congestive heart failure. J. Vet. Intern. Med., Lakewood, 19(4):537-541. <https://dx.doi. org/10.1892/0891-6640(2005)19[537:asaboo]2.0.co;2><PMid:16095171> 
Galvão A.L.B. 2009. Estresse oxidativo nos estágios finais da doença renal crônica em pequenos animais. Arch. Vet. Sci., Curitiba, 14(3):178-186. <https://dx.doi.org/10.5380/avs.v14i3.16017>

Gérard-Monnier D., Erdelmeier I., Régnard K., Moze-Henry N., Yadan J.C. \& Chaudiere J. 1998. Reactions of 1-methyl-2-phenylindole with malondialdehyde and 4-hydroxyalkenals. Analytical applications to a colorimetric assay of lipid peroxidation. Chem. Res. Toxicol. 11(10):1176-1183. <https://dx.doi. org/10.1021/tx9701790> <PMid:9778314>

Ghosh S., Bandyopadhyay S., Bhattacharya D.K. \& Mandal C. 2005. Altered erythrocyte membrane characteristics during anemia in childhood acute lymphoblastic leukemia. Ann. Hematol. 84(2):76-84. <https://dx.doi. org/10.1007/s00277-004-0933-0><PMid:15338196>

Goldschmidt M., Peña L., Rasotto R. \& Zappulli V. 2011. Classification and grading of canine mammary tumors. Vet. Pathol. 48(1):117-131. <https://dx.doi.org/10.1177/0300985810393258><PMid:21266722>

Itoh T., Uchida K., Ishikawa K., Kushima K., Kushima E., Tamada H., Moritake T., Nakao H. \& Shii H. 2005. Clinicopathological survey of 101 canine mammary gland tumors: Differences between small-breed dogs and others. J. Vet. Med. Sci. 67(3):345-347. <https://dx.doi.org/10.1292/ jvms.67.345><PMid:15805744>

Jain C.N. 1993. Essentials of Veterinary Hematology. Lea and Febiger, Philadelphia. 417p.

Kadiiska M.B., Gladen B.C., Baird D.D., Germolec D., Graham L.B., Parker C.E., Nyska A., Wachsman J.T., Ames B.N., Basu S., Brot N., Fitzgerald G.A., Floyd R.A., George M., Heinecke J.W., Hatch G.E., Hensley K., Lawson J.A., Marnett L.J., Morrow J.D., Murray D.M., Plastaras J., Roberts L.J., Rokach J., Shigenaga M.K., Sohal R.S., Sun J., Tice R.R., Van Thiel D.H., Wellner D., Walter P.B., Tomer K.B., Manson R.P. \& Barrett J.C. 2005. Biomarkers of oxidative stress study II: are oxidation of lipids, proteins and DNA markers of $\mathrm{CCl}_{4}$ poisoning? Free Radical Biol. Med., New York, 38(6):698-710. <https://dx.doi.org/10.1016/j.freeradbiomed.2004.09.017><PMid:15721980>

Kobune M., Kato J. \& Niitsu Y. 2008. Anemia in patients with cancer. Nippon Rinsho, Jap. J. Clin. Med. 66(3):524-529. <PMid:18330028>

Kumaraguruparan R., Balachandran C., Manohar B.M. \& Nagini S. 2005. Altered oxidant-antioxidant profile in canine mammary tumours. Vet. Res. Commun., New York, 29(4):287-296. <https://dx.doi.org/10.1023/ b:verc.0000048499.38049.4b > <PMid:15751580>

Lana S.E., Rutteman G.R. \& Withrow S.J. 2007. Tumors of the mammary gland, p.619-636. In: Withrow S.J. \& Vail D.M. (Ed.), Withrow and MacEwen's Small Animal Clinical Oncology. 4th ed. Saunders Elsevier, St. Louis.

Lavalle G.E., Bertagnolli A.C. \& Tavares W.L.F. \& Cassali G.D. 2009. Cox-2 expression in canine mammary carcinoma: correlation with angiogenesis and overall survival. Vet. Pathol. 46(6):1275-1280. <https://dx.doi. org/10.1354/vp.08-VP-0226-C-FL $><$ PMid:19605908>

Lucas S.R.R., Gimeno M.G., Mori C.S. \& Wirthl V.A.B.F. 2008. Evaluation of oxidant/antioxidante status in dogs with multicentric lymphoma. J. Vet. Intern. Med. 22(3):772.

Macedo T.R. 2010. Avaliação das concentrações de superóxido dismutase e da fragilidade osmótica eritrocitária em cães com linfoma multicêntrico com e sem anemia. Master's Thesis, Faculdade de Medicina Veterinária e Zootecnia. Universidade de São Paulo, São Paulo, SP. 96p.

Macewen E.G. \& Withrow S.J. 2007. Tumors of the mammary gland, p.356372. In: Withrow S.J. \& Macewen E.G. (Eds), Small Animal Clinical Oncology. 2nd ed. W.B. Saunders, Philadelphia.

Macotpet A., Suksawat F., Sukon P., Pimpakdee K., Pattarapanwichien E., Tangrassameeprasert R. \& Boonsiri P. 2013. Oxidative stress in cancerbearing dogs assessed by measuring serum malondialdehyde. BMC Vet. Res., New York, 9:101. <https://dx.doi.org/10.1186/1746-6148-9-101> <PMid:23663727>

Martins A.M.C.R.P.F., Tamaso E. \& Guerra J.L. 2002. Retrospective review and systematic study of mammary tumors in dogs and characteristics of the extracellular matrix. Braz. J. Vet. Res. Anim. Sci. 39(1):38-42. <https://dx.doi.org/10.1590/S1413-95962002000100007>

Misdorp W., Else R.W. \& Hellmén E. 1999. Histological classification of mammary tumors of the dog and the cat. In: World Health Organization international histological classification of tumors of domestic animals. 2nd ed. Vol.7. Center for Worldwide Reference on Comparative Oncology, Armed Forces Institute of Pathology in cooperation with the American Registry of Pathology and the World Health Organization Collaborating, Washington D.C.

Monteiro A.P.S., Arraes E.P.P., Pontes L.B., Campos M.S.S., Ribeiro R.T. \& Gonçalves R.E.B. 2003. Auto-exame das mamas: freqüência do conhecimento, prática e fatores associados. Revta Bras. Ginecol. Obstetr. 25(3):201-205. <https://dx.doi.org/10.1590/S0100-72032003000300009>

Oliveira L.O., Oliveira R.T., Loretti A.P., Rodrigues R. \& Driemeier D. 2003. Aspectos epidemiológicos da neoplasia mamária canina. Acta Scient Vet. 31(2):105-110. <https://dx.doi.org/10.22456/1679-9216.17079>

Pérez Y.G., Pérez L.C.G., Netto R.C.M., Lima D.S.N. \& Lima E.S. 2012. Malondialdeído e grupo sulfidrila como biomarcadores do estresse oxidativo em pacientes com lúpus eritematoso sistêmico. Revta Bras. Reumatol. 52(4):658-660. <http://dx.doi.org/10.1590/s0482-50042012000400016>

Pilz J., Meineke I. \& Gleiter C. 2000. Measurement of free and bound malondialdehyde in plasma by highperformance liquid chromatography as the 2,4- dinitrophenylhydrazine derivative. J. Chromatogr. B, Anal. Technol. Biomed. Life Sci. 742(2):315-325. <https://doi.org/10.1016/ S0378-4347(00)00174-2><PMid:10901136>

Pires A.M.T. 2007. Avaliação das reações agudas da pele e seus fatores de risco em pacientes com câncer de mama submetidas a radioterapia. Master's Thesis in Sciences, Escola Paulista de Medicina, Universidade Federal de São Paulo, São Paulo. 52p.

Ribas C.R., Dornbusch P.T., Faria M.R., Wouk A.F.P.F. \& Cirio S.M. 2012. Alterações clínicas relevantes em cadelas com neoplasias mamárias estadiadas. Arch Vet. Sci. 17(1):60-68.

Schafer F.Q. \& Buettner G.R. 2001. Redox environment of the cell as viewed through the redox of the glutathione disulfide/glutathione couple. Free Radical Biol. Med. 30(11):1191-1212. <https://dx.doi.org/10.1016/ s0891-5849(01)00480-4><PMid:11368918>

Sener D.E., Gönenç A., Akinci M. \& Torum M. 2007. Lipide peroxidation and total antioxidant status in patients with mammary cancer. Cell Biochem. Function, Chichester, 25(4):377-382. <https://dx.doi.org/10.1002/ cbf.1308> <PMid:16447143>

Shapiro S.S. \& Wilk M.B. 1965. An analysis of variance test for normality (complete samples). Biometrika 52(3/4):591-611. <https://dx.doi. org/10.2307/2333709>

Sim A.S., Salonikas C., Naidoo D. \& Wilcken D.E.L. 2003. Improved method for plasma malondialdehyde measurement by high-performance liquid chromatography using methyl malondialdehyde as an internal standard. J. Chromatogr. B, Anal. Technol. Biomed. Life Sci. 785(2):337-344. <https://dx.doi.org/10.1016/s1570-0232(02)00956-x><PMid:12554147>

Szczubial M., Kankofer M., Łopuszyński W., Dabrowski R. \& Lipko J. 2004. Oxidative stress parameters in bitches with mammary gland tumours. J. Vet. Med. A, Physiol., Pathol., Clin. Med., Berlim, 51(7/8):336-340. <https://dx.doi.org/10.1111/j.1439-0442.2004.00647.x><PMid:15533114>

Thuróczy J., Reisvaag G.J.K., Perge E., Tibold A., Szilágyi J. \& Balogh L. 2007. Immunohistochemical detection of progesterone and cellular proliferation in canine mammary tumours. J. Comp. Pathol. 137(2/3):122-129. <https://dx.doi.org/10.1016/j.jcpa.2007.05.005><PMid:17645888>

Toríbio J.M.M.L., Lima A.E., Martins Filho E.F., Ribeiro L.G.R., D’assis M.J.M.H., Teixeira R.G., Damasceno K.A., Cassali G.D. \& Neto Costa J.M. 2012. Caracterização clínica, diagnóstico histopatológico e distribuição geográfica das neoplasias mamárias em cadelas de Salvador, Bahia. Revta Ceres 59(4):427-433.<https://dx.doi.org/10.1590/S0034-737X2012000400001> 
Vail D.M. \& Thamm D.H. 2005. Hematopoietic tumors, p.732-747. In: Ettinger S.J. \& Feldman E.C. (Eds), Textbook of Veterinary Internal Medicine. 6th ed. W.B. Saunders, Philadelphia.

Vasconcelos S.M.L., Goulart M.O.F., Moura J.B.F., Manfredini V., Benfato M.S. \& Kubota L.T. 2007. Espécies reativas de oxigênio e de nitrogênio, antioxidantes e marcadores de dano oxidativo em sangue humano: principais métodos analíticos para sua determinação. Quim. Nova, São Paulo, 30(5):1323-1338. <https://dx.doi.org/10.1590/S0100-40422007000500046>
Winter J.L., Barber L.G., Freeman L., Griessmayr P.C., Milbury P.E. \& Blumberg J.B. 2009. Antioxidant status and biomarkers of oxidative stress in dogs with lymphoma. J. Vet. Intern. Med., Philadelphia, 23(2):311-316. <https://dx.doi.org/10.1111/j.1939-1676.2009.0273.x><PMid:19210312>

Wintrobe M.M. 2001. Clinical Hematology. 7th ed. Lea and Febiger, Philadelphia. 2408p.

Zuccari D.A.P.C., Santana A.E. \& Rocha N.S. 2001. Fisiopatologia da neoplasia mamária em cadelas-revisão. Clín. Vet., São Paulo, 6(32):50-54. 